\title{
Okul Öncesi Eğitim Öğretmenlerinin Disiplin, Sınıf Yönetimi ve İstenmeyen Davranışlar Hakkındaki İnançları*
}

\section{Preschool Teachers' Beliefs about Discipline, Classroom Management, and Disruptive Behaviors}

\author{
Yasin ÖZTÜRK ${ }^{* *}$, Merve GANGAL ${ }^{* * *}$
}

ÖZ: Bu araştırmada öğretmenlerin istenmeyen davranışlar ile baş etme, sınıf yönetimi yeterlilikleri ve disiplin uygulamaları ile ilgili inanç ve görüşlerinin incelenmesi amaçlanmıştır. Çalışma nitel araştırma yöntemlerinden durum çalışması yöntemi ile yapılmıştır. Çalışma 2012-2013 eğitim öğretim yılında, Milli Eğitim Bakanlığına bağlı bir anaokulundan seçilen 3 okul öncesi eğitim öğretmeni ile yürütülmüştür. Veriler yapılandırılmam311ş sinıf içi gözlemler, öğretmenler ile yapılan yarı yapılandırılmış mülakatlar ve öğretmenlerin günlük planlarından elde edilmiştir. Verilerin yazılı dökümleri yapıldıktan sonra nitel veri analiz aracı olan NVIVO 8 programına aktarılarak içerik analizi ile çözümlemesi yapılmıştır. Çalışma sonucunda öğretmenlerin inançları ile sınıf içi uygulamaları arasında bazı benzerlikler olmasına rağmen farklılıkların da olduğu tespit edilmiştir. Öğretmenlerin inançlarının tersine sınıf içinde daha çok geleneksel sınıf yönetimi stratejilerini kullandıkları görülmüştür.

Anahtar sözcükler: okul öncesi, istenmeyen davranışlar, sınıf yönetimi, öğretim stratejileri, disiplin

\begin{abstract}
In this research, it is aimed to explore the beliefs and the views of preschool teachers about discipline, classroom management, and dealing with disruptive behaviors in their classrooms. The study was done through case study methods as one of qualitative research methods. It was conducted in 2012-2013 educational years and with 3 preschool education teachers who were selected from a preschool dependent on the Ministry of National Education. The data was gathered through unstructured in-class observations, semi-structured interviews with the teachers, and document analysis of teachers' plans related to daily routines. After transcription, the data were transferred to NVIVO 8 program, which is a qualitative data analysis tool, and its analysis was made through content analysis. As a result of study, it was found out that there are clear distinctions with teachers' classroom practices and their classroom management discourses although there were some similarities between their beliefs and practices. In contrast to their beliefs, the teachers were observed to use more traditional classroom management strategies for the disruptive behaviors.
\end{abstract}

Keywords: Preschool, disruptive behaviors, classroom management, teaching strategies, discipline

\section{GíRiş̧}

Okul öncesi dönemde çocuklar okul ortamına ilk girdiklerinde bu yeni ortamın kendi çevresi dışından farklı bir çevre olduğunu ve bu çevrenin uyulması gereken farklı kurallara sahip olduğunu fark ederler. Bu dönemde çocuklar kendi yapılandırdıklarının üzerine yeni bilgileri alırken kendilerini korumayı, başkalarıyla paylaşmayı, haklarına sahip çıkmayı ve başkalarının fiziksel ve duygusal haklarına zarar vermemeyi öğrenirler (Yavuzer, 2006). Çocukların yaşantısında belirleyici olan bu ilk kurumsal okul deneyiminin çocukların eğitim ve yaşam ortamlarında bilinçli düzenlemeler yapılarak sürdürülmesi çocukların kendi yaşantılarında ve toplumsal düzende daha iyi bir geleceğe sahip olması için gerekli görülmektedir (Gezgin, 2009).

\footnotetext{
* Bu çalışma, Yrd. Doç. Dr. Yasin Öztürk danışmanlığında yapılan “Okul Öncesi Eğitim Öğretmenlerinin Sınıfta İstenmeyen Davranışlarla Başa Çıkmaya Yönelik Uygulamaları ve Sınıf Yönetimi Stratejileri Hakkındaki İnançlarının İncelenmesi” isimli yüksek lisans tez çalışmasının bir bölümünden özetlenerek hazırlanmıştır.

** Yrd. Doç. Dr., KTÜ Fatih Eğitim Fakültesi, Trabzon/Türkiye, byozturk@ktu.edu.tr

*** Öğr. Gör., KTÜ Fatih Eğitim Fakültesi, Trabzon/Türkiye, mervegangal@ktu.edu.tr
} 
Sınıfta etkili bir öğrenme ortamı oluşturma amacıyla çocukların rahatsız edici ya da uygun olmayan davranışlarının yönetimini sağlamanın öğretmenler için büyük çaba gerektiren konulardan birisi olduğu bilinmektedir. Sinıfta oluşturulan düzeni bozan, eğitim-öğretim faaliyetlerinin planlandığ gibi yürütülmesini engelleyen, öğretmen-öğrenci iletişimini olumsuz etkileyen ve sınıfın genel disiplin anlayışına aykırı düşen davranışlar genel olarak sınıfta istenmeyen davranışlar olarak adlandırılır (Erol, 2006; Çakır, 2010; Yaman, 2010). İstenmeyen davranışların tanımlanması ve bunlara yönelik disiplin stratejilerinin teorik temelleri incelendiğinde farklı yaklaşımların olduğu gözlenmektedir. Skinner, Watson ve Thorndike gibi davranışçı kuramcılar çocukların olumlu ve olumsuz davranışları öğrenme yoluyla kazandığını ya da değiştirdiğini savunmaktadırlar (Özgün, 2008). Davranışçı yaklaşıma göre çocuklar çevrelerinde ki uyaranlara ve yetişkinlere göre davranışlarını model alma yoluyla şekillendirirler. Olumlu davranışlar gibi istenmeyen davranışlar da gözlemler, pekiştireçler (olumlu ve olumsuz) aracılığı ile edinilir (Neisworth ve Buggey, 2009; Özgün, 2008). Öğretmenler çocukların davranış sürecini ve sıralamasını iyi takip etmeli, çocukların davranışlarının ön uyarıcılarını da dikkate alarak kendi yönetim stratejilerini oluşturmalıdırlar. Bu stratejiler doğrultusunda davranışların neden sonuç ilişkisi içerisinde değerlendirildiği daha nitelikli bir sınıf yönetimi ve disiplin gerçekleşmiş olacaktır. Diğer taraftan yapılandırmacı yaklaşımda ise Vygotsky ve Piaget'nin çocukların davranışlarına ilişkin görüşlerinin daha farklı olduğunu görülmektedir. Davranışların kazanılmasında ve öğrenmenin gerçekleşmesinde çocukların algılaması ve bilişsel süreçleri önemli belirleyicilerdir. Çocuklar kendi tecrübelerini anlamlandırmaları yani farkında olmaları sonucunda kendi davranışlarını etkin bir şekilde yapılandırırlar (Nourt, 2009). İstenmeyen davranışların sergilenmesinde çocukların bu davranışın farkında olabilecek bilişsel yeterliliğe sahip olmadıkları düşünülür. Çünkü Piaget çocukların düşünüş tarzının yetişkinlerden farklı olduğunu ve bu nedenle davranışlarını da yetişkinlerden farklı şekillendirdiklerini belirtmektedir (Erdem ve Demirel, 2002; Özgün, 2008). Piaget'nin modeline sosyalleşme vurgusunu ekleyerek, Vygotsky çocukların davranışlarının çoğunu sosyal-kültüre bağlam içinde başkalarından gözlemleyerek öğrendiğini ileri sürmektedir (Nourt, 2009). Bu yüzden istenmeyen davranışlar çocuğun kendi sosyal bağlamından bağımsız olarak tanımlanmaması gerekir. Öğretmen ve önemli diğerler (aile, arkadaş, sosyal çevre vb.) çocuğun davranışlarını model aldığ1 rehber konumundadırlar. Bu rehberlerin desteğiyle ("scaffolding"-yap1 iskelesi) çocuk kendi potansiyel gelişim alanı çerçevesi içinde olumlu davranışları kazanacaktır (Katz ve Chard, 2000).

Sınıfta istenmeyen davranışlar ile başa çıkmanın en önemli adımı ilk olarak sorun davranışı tespit etmek ve nedenlerini bulmaktır. Öğretmenin sınıfta problem oluşturan durumu iyi bilmesi onu ortadan kaldırabilmesini de kolaylaştıracaktır (Kapucuoğlu Tolunay, 2008). Aksi takdirde olumsuz-istenmeyen davranışlar sergileyen çocuklar sınıf içerisinde oluşturulmuş öğrenme firsatlarını bozabilir buna bağlı olarak öğretmenler kendilerini engellenmiş hissedebilirler. Sorun davranışlar ile başa çıkmada her öğretmenin yöntem ve teknikleri farklılık gösterebilir. Fakat temel olarak öğretmenlerin sınıflarının yapısına ve çocukların özelliklerine göre kendi disiplin yöntemlerini geliştirmesi ve uygulaması esastır (Tertemiz, 2005). Sınıf yönetiminde etkili bir öğretmenden öğrencilerin ilgi, beklenti ve gereksinimlerini tanıması beklenir. Bu nedenle öğretmenlerin sınıf yönetiminde keskin tutumlardan ve emreden tavırlardan uzak durması, öğrencilerin ihtiyaçları doğrultusunda kendi özdenetimlerini kazanmalarını sağlayıcı bir yönetim anlayışı benimsemesi önemli görülmektedir (İlgar, 2007). Sınıf ortamında olumlu bir iklimin olması ve çocukların istenilen davranış değişikliklerini gösterebilmesinin sınıf içinde belli bir düzen oluşturma ve bunun sürekliliğini sağlama ile mümkün olacağı anlaşılmaktadır. Ayrıca çocukların kendilerini önemli ve rahat hissedecekleri ve düşüncelerini kolaylıkla belirtebilecekleri bir ortam oluşturulması da istenmeyen davranışlar ve sınıf içi problemlerin önüne geçmede önemli görülmektedir (Ferk, 2009). Yapılan bazı araştırmalara göre sınıfın iyi bir şekilde yönetilebilmesi öğretmenin kuralları açık ve net bir şekilde ortaya koymasına ve bu kuralların sürekli olmasına bağlıdır (Bear, 1998; Carter \& Doyle, 2011; 
Webster-Stratton, 1999). Bir başka çalışmada ise öğretmenlerin sınıf yönetimi konusunda esnek olması gerektiği, çocukların davranışlarına göre ödül ve cezanın yerinde kullanılmasının önemli olduğu vurgulanmıştır (Hoy \& Weinstein, 2006). Öğretmenin aldığı eğitimin sınıf içi yönetimini oluşturmasında etkili olduğu belirtilmektedir (Hiralall \& Martens, 1998).

Sınıfta düzen ortamının oluşturulması genel olarak disiplin kavramıyla açıklanabilir. Sınıf içindeki olumsuzlukları ortadan kaldırmak ve çocukların içinde bulundukları çevreye uyumlu davranmalarını desteklemek sınıf içindeki disiplin anlayışının temelini oluşturmalıdır. Toplumda var olan geleneksel algının aksine çocukların öğretmenden veya büyüklerinden korkarak değil, çekindikleri bir kişi olmadan kurallara uyma ve düzeni sağlama davranışı göstermeleri doğru disiplin uygulamasının gereğidir (Kısa, 2009; Cüceloğlu, 2001). Eğitimde disiplin süreci eğitim faaliyetlerini en iyi şekilde uygulamak adına belli bir düzenin sağlanması ve hedeflenen amaçlara ulaşılıncaya kadar da bu düzenin devam ettirilmesi olarak tanımlanabilir (Esen, 2006). $\mathrm{Bu}$ doğrultuda öğretmenlerin sınıflarında oluşturmaya çalışacakları ortam, ortak olmakla birlikte her öğretmenin bu ortamı oluşturma ve uygulama şekli farklı olacaktır. Bu aşamada öğretmenlerin sınıf yönetimi ve disiplin uygulamaları ile ilgili bilgi ve tecrübelerinin farklılığı uygulamaların niteliğini etkileyecektir. Öğretmenin alanında bilgili olması, sınıf yönetiminde ve çocukları tanımada etkin olması sınıfta ortaya çıkan durumlara müdahale etmesini kolaylaştıracaktır (Gettinger \& Fischer, 2015). Öğretmenin programda yer alan eğitim-öğretim faaliyetlerini doğru bir şekilde planlayabilmesi ve bu uygulamaları yapabilecek mesleki yeterliliğe sahip olması gereklidir. Öğretmenin sınıfta planlarını uygularken çocukları da iyi gözlemleyebilmesi ve ortaya çıkabilecek olumsuzlukları iyi yönetebilecek olgunluğa sahip olması önemlidir (Akçadağ, 2005; Öztürk, 2002). Aksi takdirde geleneksel disiplin anlayışı ve tutarsız-anlık müdahaleler, çocukta olması gereken disiplin anlayışının yerleşmesine olumsuz etki edecektir.

Çocukların istenmeyen davranışlarını önlemek için uygulanan çağdaş ve farklı yöntemlere bir örnek Piramit Modelidir. Bu model çocukların "zor davranışlarını" veya istenmeyen davranışlarını önlemek ve sosyal yeterliğini desteklemek için Vanderbilt Üniversitesi Erken Yaşta Öğrenmede Sosyal ve Duygusal Temeller Merkezi tarafından geliştirilmiştir. Piramit Modeli dört bölümden oluşmaktadır: (1) çocuklarla olumlu ilişkiler, (2) yüksek kaliteli destekleyici ortamlar, (3) sosyal ve duygusal öğretim stratejileri ve (4) yoğun bireyselleştirilmiş müdahaleler (Bredekamp, 2015, s.240). Yapılan araştırmalar Piramit modelinin çocukların istenmeyen davranışlarını azalttığını ve sosyal etkileşimlerini arttırdığını ortaya çıkarmıştır (Bredekamp, 2015). Sınıfta istenmeyen davranışlara müdahale programlarına bir başka örnek ise "Eşsiz Yıllar (EY) Dinozor - Okula Yönelik Sosyal Beceri ve Problem Çözme Eğitimi Programıdır (Incredible Years) (Webster-Stratton ve Reid, 2003). Farklı ünitelerden oluşan program çocukların okula hazır bulunmalarını ve sosyal duygusal yeterliklerini desteklemekte; empati, problem çözme ve öfke kontrolü gibi becerilerini geliştirmeyi hedeflemektedir.

Alanda yapılan çalışmalar incelendiğinde sınıfta istenmeyen davranışların belirlenmesi, görülme sıklıklarının ve nedenlerinin araştırılması üzerine yapılmış birçok araştırma olduğu görülmüştür (Kapucuoğlu Tolunay, 2008; Özer, 2009; Sadık, 2004). Sınıf disiplinini sağlama ve istenmeyen davranışların ortadan kaldırılmasına yönelik yöntemleri ortaya koyan çalışmalar da yapılmıştır (Sipahioğlu, 2008; Yılmaz, 2007). Fakat öğretmenlerin istenmeyen davranışlar ile baş etme, sınıf yönetimi yeterlilikleri ve disiplin uygulamaları ile ilgili inanç ve görüşlerinin araştırılması ile ilgili yeterli çalışma yapılmamıştır. Bu çalışma bir bakıma öğretmenlerin kendi yetenek ve bilgilerinin ne kadar farkında olduğunu da ortaya çıkartmayı amaçladığı için önemli görülmektedir. Öğretmenlerin yapabildiklerinin ve yapamadıklarının farkında olup kendilerini bu yönde geliştirmeye çalışmalarının mesleklerinde başarılı olmaları ve planladıkları eğitim amaçlarına ulaşabilmeleri için gerekli olduğu düşünülmektedir. 


\section{YÖNTEM}

\subsection{Araştırmanın İçeriği ve Modeli}

$\mathrm{Bu}$ çalışmada nitel araștırma yöntemlerinden durum çalıșması yöntemi kullanılmıștır. Öğretmenlerin etkinlik planları incelenmiş ve öğretmenler ile mülakatlar yapılmıştır. Ayrıca öğretmenler ve çocuklar sınıf ortamında gözlenerek davranışları ve inançları ile ilgili ayrıntılı bilgiler elde edilmeye çalışılmıştır. Durum çalışmasını yapan kişi, araştırmanın yapıldığı doğal ortama girerek araştırma grubuna eşlik etmiş, onlar ile iletişime girmiş ve araştırmak istediği durum ya da durumlara odaklanmıştır. Araştırmacı bilgileri doğal ortamında toplamış ve kendinin ve katılımcıların bakış açılarını çalışmaya yansıtmıştır (Gall, Gall \& Borg, 1999; Büyüköztürk ve diğerleri, 2014).

\section{2. Çalışma Grubu}

Bu çalışmanın yapıldığı grup 2012-2013 eğitim öğretim yılında, Trabzon'da Milli Eğitim Bakanlığına bağlı bir anaokulunda çalışan ve gönüllülük esasına göre seçilen üç okul öncesi eğitim öğretmenlerinden oluşmaktadır. Araştırma grubunda yer alan öğretmenler Ö-1, Ö-2 ve Ö-3 olarak kodlanmış ve çalışma öğretmenlerin doğal çalışma ortamları olan sınıflarında yürütülmüştür.

Ö-1, 29 yaşında olduğunu ve 11 yıldır okul öncesi öğretmenliği yaptığını belirtmiştir. Açık öğretim fakültesi mezunu olan Ö-1'in sınıfında 6 yaş grubu 26 çocuk yarım gün eğitim görmektedir. Ö-2, 25 yaşındadır ve 5 yıldır okul öncesi öğretmenliği yaptığını belirtmiştir. Açık öğretim fakültesi mezunu olan Ö-2'nin sınıfında 5-6 yaş grubu 24 çocuk yarım gün eğitim görmektedir. Ö-3, 27 yaşındadır ve lisans eğitimini okul öncesi eğitim öğretmenliği alanında ve örgün eğitim veren bir fakültede tamamladığını belirtmiştir. 5 yıldır okul öncesi öğretmenliği yapan Ö-3'ün sınıfında 5 yaş grubu 19 çocuk tam gün eğitim görmektedir.

\subsection{Verilerin Toplanması}

McMillan (2004), durum çalışmaları yapılırken durumu daha derinlemesine betimlemek ve araştırmanın amacına uygun bir şekilde yürütülebilmesine olanak sağlamak için iki ya da daha fazla veri toplama yöntemi kullanılmasının gerekli olduğunu belirtmiştir. Bu bağlamda veriler yapılandırılmamış sınıf içi gözlemler, öğretmenler ile yapılan yarı yapılandırılmış mülakatlar ve öğretmenlerin günlük planlarının incelenmesi ile elde edilmiştir. Araştırmacı birinci aşamada, seçilen her öğretmenin sınıfinda haftada bir kez 2 saat olmak üzere 7 haftada toplam 14 saat gözlem yapmış ve bu gözlemleri yazılı olarak kaydetmiştir. Gözlemler yapılandırılmamış gözlem metodu ile yapılmıştır. İkinci aşama olarak öğretmenler ile iki ayrı yarı-yapılandırılmış mülakat yapılmış ve her biri 25 dakika süren bu görüşmeler ses kayıt cihazı ile kaydedilerek daha sonra araştırmacı tarafindan yazıya dökülmüştür. Üçüncü aşamada seçilen öğretmenlerin gözlem yapılan günlerdeki etkinlik planları araştırmacı tarafindan yazıya dökülerek doküman analizi yapılmıştır. Sınıf içi gözlemler ve mülakatlardan elde edilen verilere ek olarak yapılan plan incelemeleri, araştırmacının veri üçlemesi yaparak çalışmanın iç geçerliliğini sağlamasına olanak vermiştir (Fraenkel \& Wallen, 2008; Stake, 1995).

\subsection{Verilerin Analizi}

Sınıf içi gözlemler, öğretmenler ile yapılan mülakatlar ve öğretmenlerin günlük planlarından elde edilen veriler, yazılı dökümleri yapıldıktan sonra nitel veri analiz aracı olan NVivo 8 programına aktarılarak içerik analizi ile çözümlemesi yapılmıştır. İçerik analizinde yapılan işlem, birbirine benzeyen verileri belirli kavramlar ve temalar çerçevesinde bir araya getirmek ve bunları okuyucunun anlayacağı biçimde düzenleyerek yorumlamaktır (Yıldırım \& Şimşek, 2006). Programa yüklenen yazılı metinler satır satır okunmuş ve veriler arasında yer alan anlamlı bölümlerin kodlanması yapılmıştır. Kodlamaların yapılmasında çalışmanın amaçları doğrultusunda belirlenen, öğretmenlerin sınıf içi davranışları ve sınıf yönetimi ile ilgili 
inançlarının değerlendirildiği genel çerçeveden yararlanılmıştır. NVivo 8 programı ile kodlamalar oluşturulmuş ve bu kodlamalar yorumlanarak bulgular elde edilmiştir.

\section{BULGULAR}

$\mathrm{Bu}$ kısımda sınıflarda yapılan gözlemler, öğretmenler ile yapılan mülakatlar ve öğretmenlerin günlük planlarının irdelenmesi sonucunda her öğretmenin disiplin ve sınıf yönetimi ile ilgili davranışları ve kendilerine inançları ayrı ayrı ele alınmıştır. Öğretmenlerin disiplin ve sınıf yönetimi profilleri ile sınıfta sergiledikleri davranışlar ve sınıf yönetimi ile ilgili inanç ve düşünceleri olarak iki başlık altında incelenmiştir.

\section{1. Ö-1'in Disiplin ve Sınıf Yönetimi Profili}

Bu kısımda Ö-1'in sınıfta sergilediği davranışlar ve sınıf yönetimi ile ilgili inanç ve düşüncelerinin yer aldığı bulgular ele alınacaktır.

\subsection{1. Ö-1’in Sınıfta Sergilediği Davranışlar}

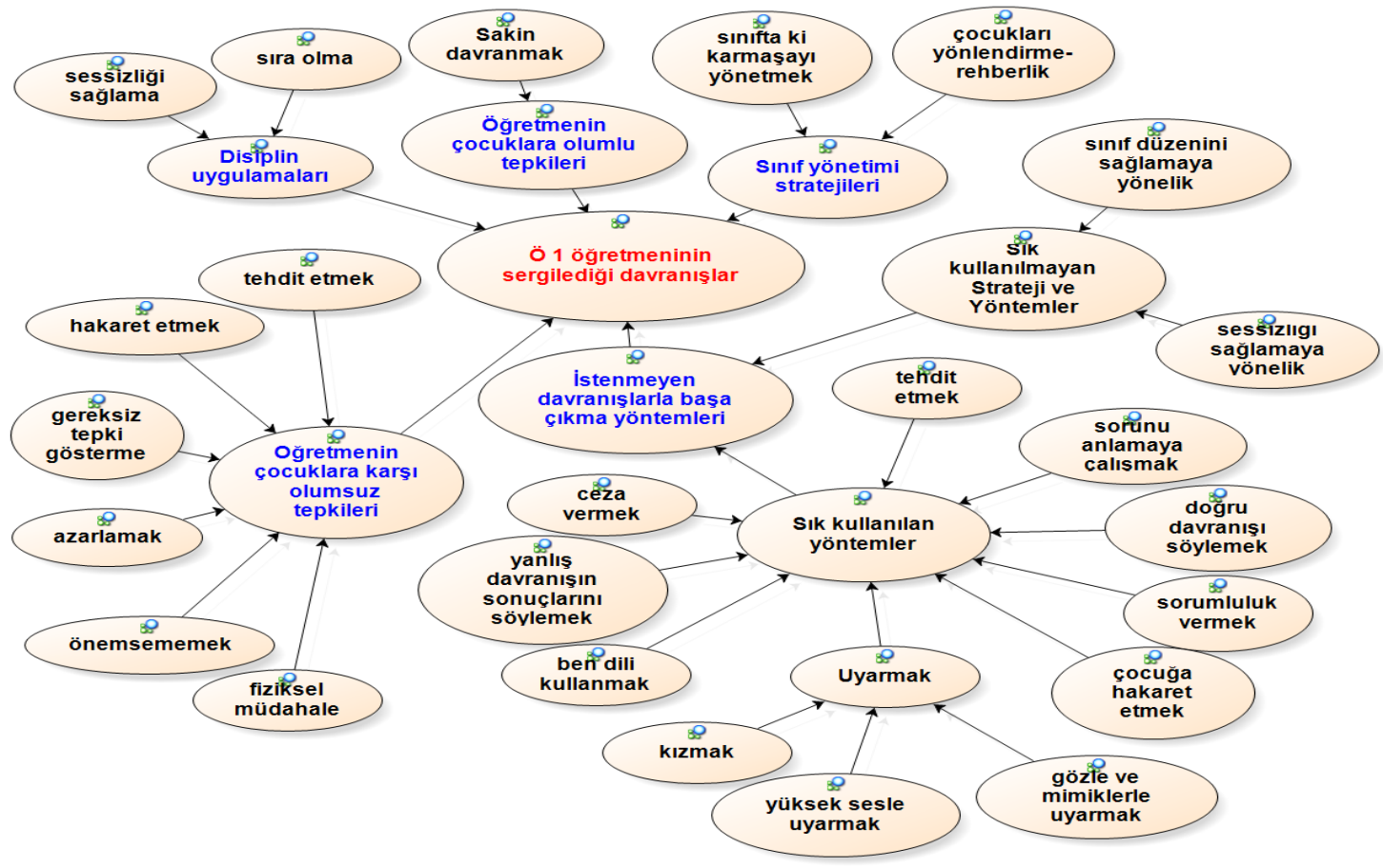

\section{Şekil 1. Ö-1'in sınıfta sergilediği davranışlara ait kodlamaların gösterildiği model}

Ö-1'in sınıfında yapılan gözlemler ve öğretmenin günlük planlarının incelenmesinden elde edilen bulgulara ilişkin kod ve temalar Şekil 1'de gösterilmiştir. Ö-1'in sınıfta sergilediği davranışların gösterilmesi amacıyla oluşturulan modelde öğretmenin disiplin uygulamaları, sınıf yönetimi stratejileri, istenmeyen davranışlarla başa çıkma yöntemleri, çocuklara karşı olumlu davranışları, çocuklara karşı olumsuz davranışları ve alt başlıkları gösterilmiştir.

Şekil 1'e bakıldığında Ö-1'in sınıfta istenmeyen davranışlarla başa çıkma yöntemlerinden sık kullanılan yöntemleri daha fazla kullandığı görülmektedir. Sık kullanılan yöntemlerden "ceza verme", "uyarma" ve "sorumluluk verme" de dâhil olmak üzere dokuz tanesinin Ö-1'in kullandığı yöntemler arasında olduğu Şekil 1'de görülmektedir. Şekil 1'e göre Ö-1 sınıfında sık 
kullanılmayan strateji ve yöntemlerden ise "sessizliği sağlamaya yönelik" ve "sınıf düzenini sağlamaya yönelik” kendi oluşturduğu yöntemleri kullanmaktadır.

Gözlemler sirasında bir gün müdürle görüştükten sonra sınıfa gelen Ö-1 öğretmeninin oyuncakları dağıtarak oynadıkları için çocukları yüksek sesle uyardığı ve bazılarına da ceza verdiği (köşede bekletme cezası) görülmüştür. Oysaki sınıfta yapılan farklı zamanlardaki gözlemlerde çocukların zaten sürekli karışık bir şekilde oynadığı ve öğretmenin bununla ilgili gözlem sırasında bir uyarıda bulunmadığı gözlenmiştir.

\subsection{2. Ö-1'in Sınıf Yönetimi ile İlgili İnanç ve Düşünceleri}

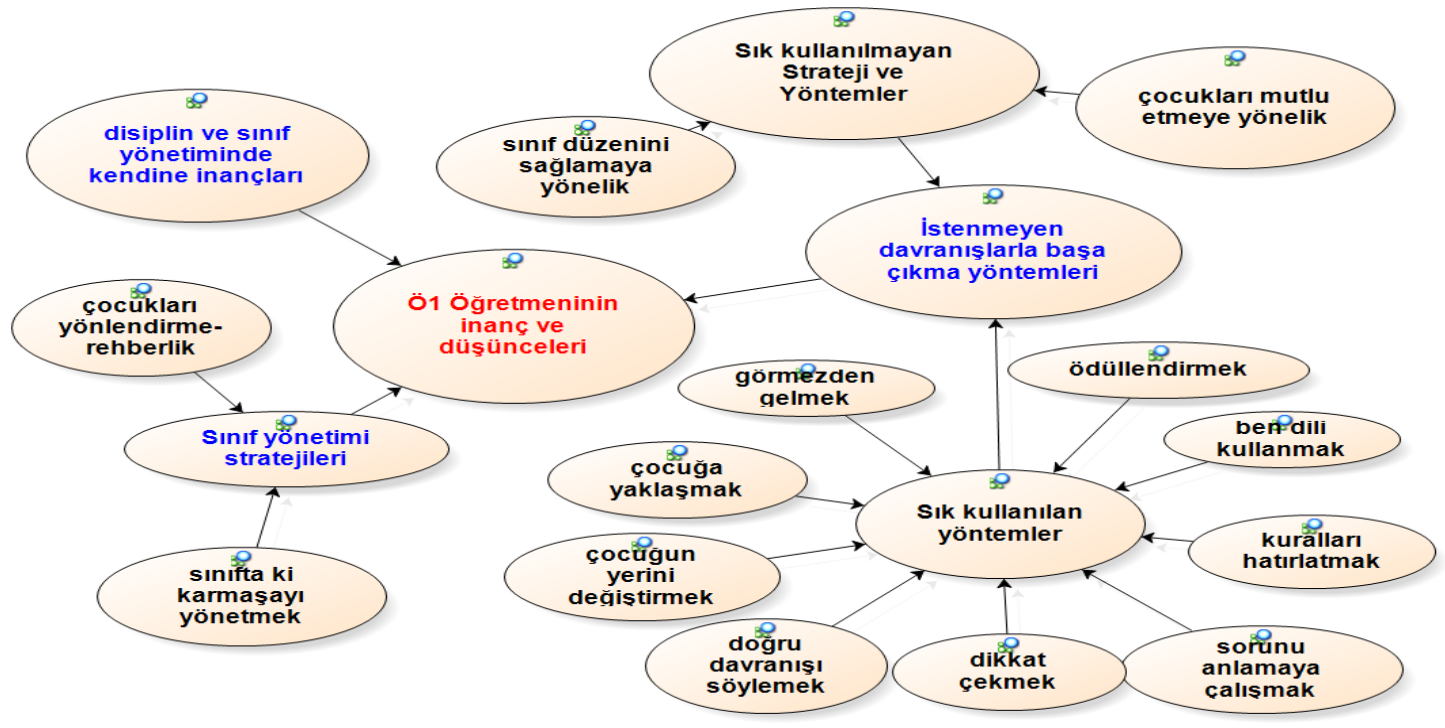

Şekil 2. Ö-1'in sınıf yönetimine ilişkin inanç ve düşüncelerine ait kodlamaların gösterildiği model

Ö-1 ile yapılan mülakatların incelenmesinden elde edilen bulgulara ilişkin kod ve temalar Şekil 2'de gösterilmiştir. Ö-1'in sınıf yönetimi ile ilgili inanç ve düşüncelerinin gösterilmesi amaciyla oluşturulan modelde öğretmenin sınıf yönetimi stratejileri, disiplin ve sınıf yönetiminde kendine inançları ile istenmeyen davranışlar ile başa çıkma yöntemleri ve alt başlıkları gösterilmiştir.

Şekil 2 incelendiğinde Ö-1'in sınıf yönetimi stratejilerinden yalnızca "çocukları yönlendirme ve rehberlik" ve "sinıftaki karmaşayı yönetmek" uygulamaları ile ilgili görüş bildirdiği görülmektedir. Ö-1'in sınıfta istenmeyen davranışlarla başa çıkma yöntemlerinden sık kullanılan yöntemler ile ilgili daha fazla görüş belirttiği ve "görmezden gelme", "dikkat çekme" ve "ödüllendirme" yöntemleri de dâhil olmak üzere dokuz adet davranışı kullandığını belirttiği Şekil 2'de görülmektedir.

Ö-1 disiplin ve sınıf yönetiminde kendine inancı ve bu konuda kendine duyduğu güveni şu şekilde ifade etmektedir;

Meslekteki 11. yllım olmasının verdiği tecrübeyle sınıf yönetiminde etkili olabildiğimi düşünüyorum. Sürekli kendimi geliştirmeye çalıştı̆̆ım için sınıfta olabilecek olumsuz durumlara karşı kendimi yeterli ve bilgili hissediyorum. Sinıf disiplinini sağlayamadığımı düşündüğüm durumlarda çocukların gelişim özelliklerine dikkat ederek planlarımda daha etkili yöntemler kullanıyorum. Üniversitede aldiğım ĕgitim tamamen yeterli değil ama üstüne bir şeyler koyduğum için bu tecrübe ile disiplini sağlama ve çocuklara faydalı olabilme konusunda sıkıntı yaşamıyorum. 
Ö-1'in sınıfinda ki gözlemler, Ö-1 ile yapılan mülakatlar, Ö-1'in günlük planlarının incelenmesi ve Şekil 1 ile Şekil 2'nin karşılaştırılması sonucunda Ö-1'in disiplin ve sınıf yönetiminde kendine inançları ile sergilediği davranışlar arasında bazı farklılıklar olduğu görülmektedir. Bu farklılıklara ilişkin yorumlar tartışma kısmında verilecektir.

\section{2. Ö-2'nin Disiplin ve Sınıf Yönetimi Profili}

Bu kısımda Ö-2'nin sınıfta sergilediği davranışlar ve sınıf yönetimi ile ilgili inanç ve düşüncelerinin yer aldığı bulgular ele alınacaktır.

\subsection{1. Ö-2'nin Sınıfta Sergilediği Davranışlar}

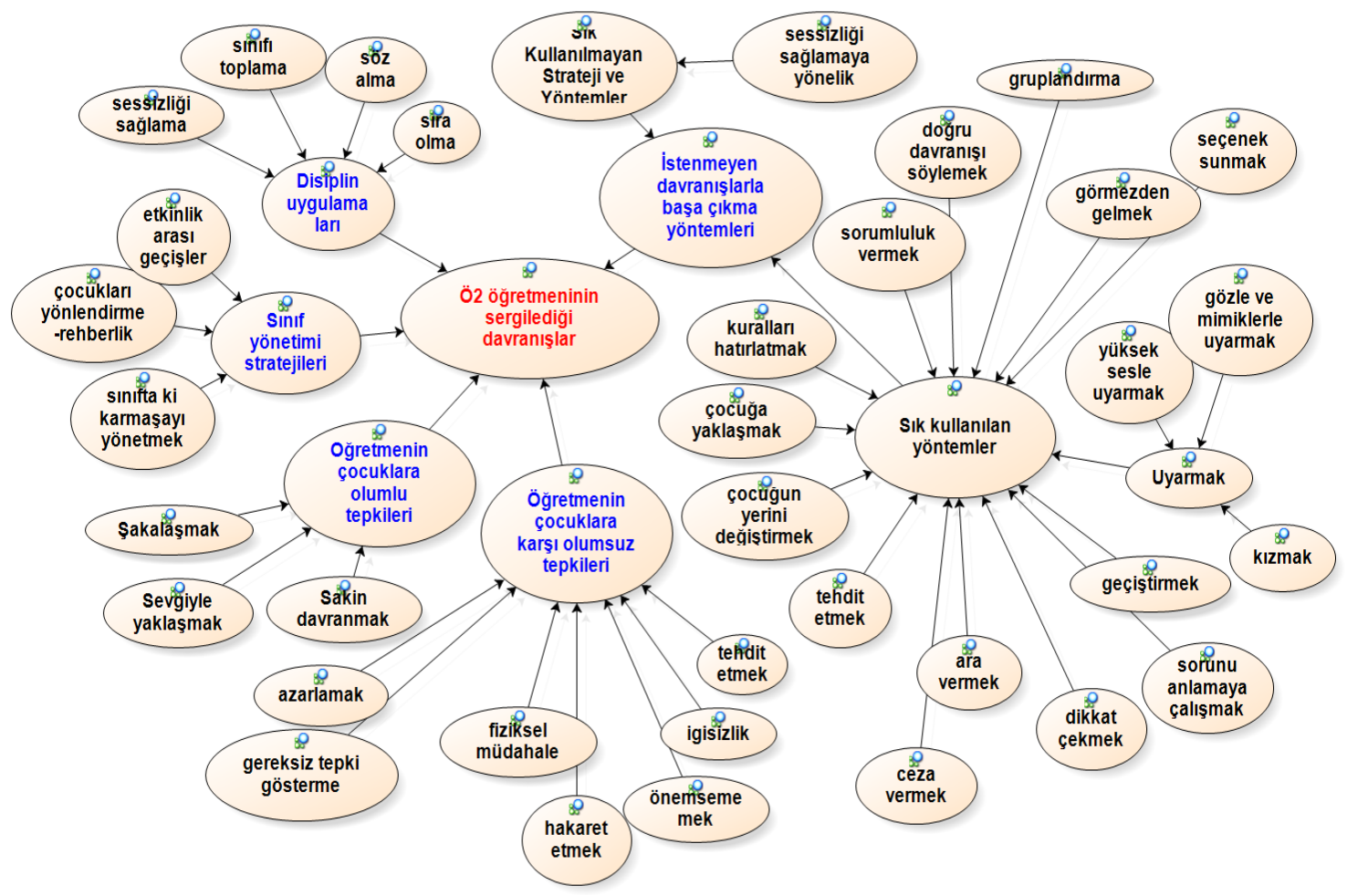

\section{Şekil 3. Ö-2'nin sınıfta sergilediği davranışlara ait kodlamaların gösterildiği model}

Ö-2'nin sınıfında yapılan gözlemler ve öğretmenin günlük planlarının incelenmesinden elde edilen bulgulara ilişkin kod ve temalar Şekil 3’te gösterilmiştir. Ö-2'nin sınıfta sergilediği davranışların gösterilmesi amacıyla oluşturulan modelde öğretmenin disiplin uygulamaları, sınıf yönetimi stratejileri, istenmeyen davranışlarla başa çıkma yöntemleri, çocuklara karşı olumlu davranışları ve çocuklara karşı olumsuz davranışları ve alt başlıkları gösterilmiştir.

Şekil 3'e bakıldığında Ö-2'nin sınıfta istenmeyen davranışlarla başa çıkma yöntemlerinden sık kullanılan yöntemleri daha fazla kullandığı görülmektedir. Sik kullanılan yöntemlerden "görmezden gelmek", "uyarma" ve "sorumluluk verme" de dâhil olmak üzere araştırma da kodlanan on beş yöntemin Ö-2'nin kullandığ 1 yöntemler arasında olduğu görülmektedir. Ayrıca Ö-2 sınıfında sık kullanılmayan "sessizliği sağlamaya yönelik" yöntemleri kullanmaktadır.

Sınıf içi gözlemlerde Ö-2' nin sınıfında güzel bir disiplin ortamı olduğu ve çocukların genel olarak sınıf içi kurallara uyduğu görülmüştür. Bir gözle sırasında Ö-2 geç geleceği için 
sınıfla farklı bir öğretmen ilgilenirken sınıf ortamının çok farklı olduğu ve çocukların öğretmenleri olmadığında disiplin ve sınıf kurallarına uymadığı dikkat çekmiştir. Ö-2 sınıfa geldiğinde bu duruma neredeyse tüm olumsuz öğretmen tepkilerini ( azarlamak, gereksiz yere tepki göstermek, hakaret etmek ve tehditte bulunmak) kullanarak tepki vermesi dikkat çekmiştir.

\subsection{2. Ö-2’nin Sınıf Yönetimi ile Illgili İnanç ve Düşünceleri}

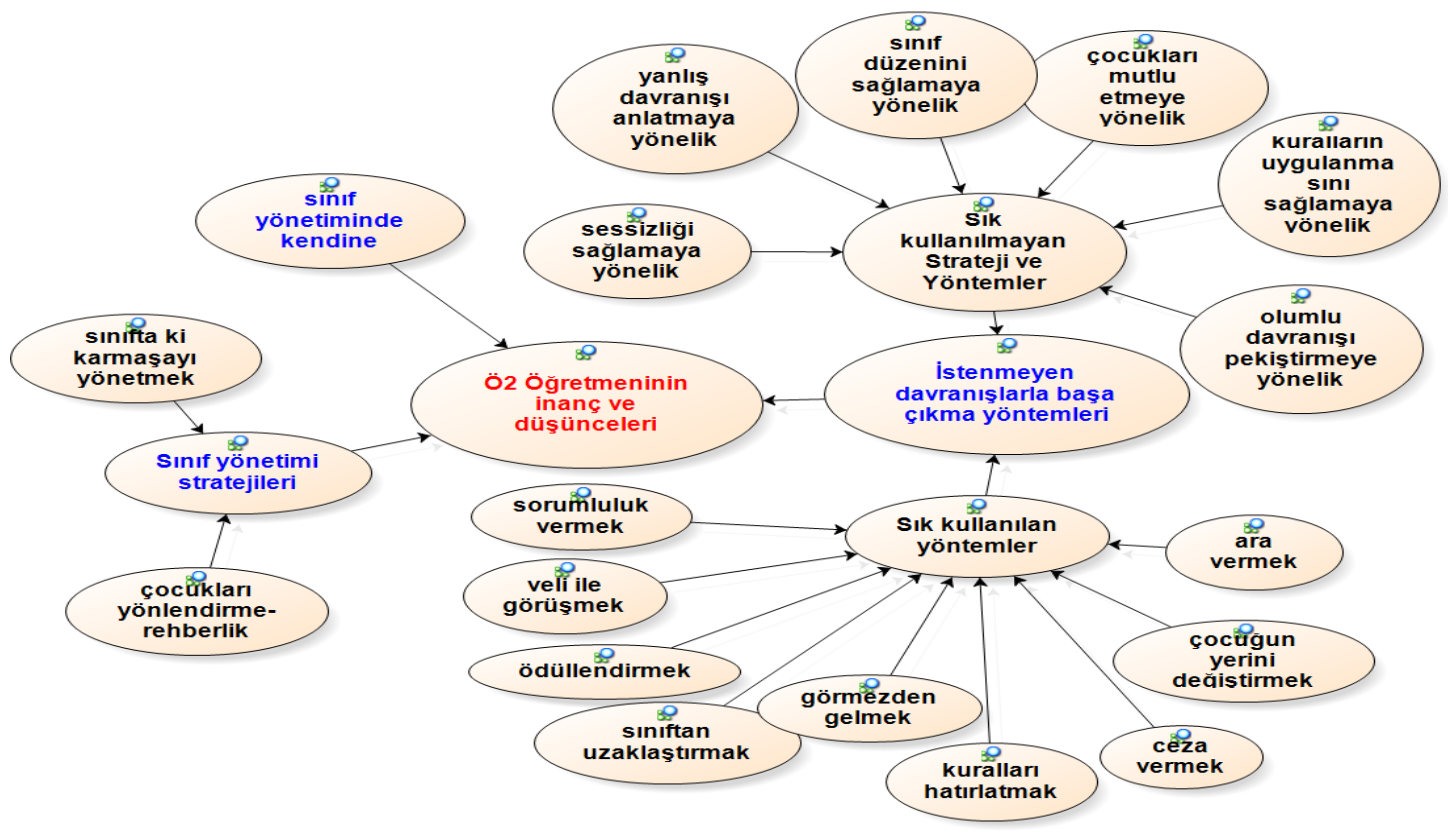

Şekil 4. Ö-2'nin sınıf yönetimine ilişkin inanç ve düşüncelerine ait kodlamaların gösterildiği model

Ö-2 ile yapılan mülakatların incelenmesinden elde edilen bulgulara ilişkin kod ve temalar şekil 4'te gösterilmiştir. Ö-2'nin sınıf yönetimi ile ilgili inanç ve düşüncelerinin gösterilmesi amaciyla oluşturulan modelde öğretmenin sınıf yönetimi stratejileri, disiplin ve sınıf yönetiminde kendine inançları ile istenmeyen davranışlar ile başa çıkma yöntemleri ve alt başlıkları gösterilmiştir.

Şekil 4 incelendiğinde Ö-2'nin sınıf yönetimi stratejilerinden yalnızca "çocukları yönlendirme ve rehberlik" ve "sınıftaki karmaşayı yönetmek" uygulamaları ile ilgili görüş bildirdiği görülmektedir. Ö-2'nin sınıfta istenmeyen davranışlarla başa çıkma yöntemlerinden sık kullanılan yöntemler ile ilgili daha fazla görüş belirttiği ve "görmezden gelmek", "sorumluluk verme" ve "ödüllendirme" yöntemleri de dâhil olmak üzere dokuz adet davranış1 kullandığını belirttiği Şekil 4'te görülmektedir.

Ö-2 disiplin ve sınıf yönetiminde kendine inancını ve bu konudaki düşüncelerini şu şekilde ifade etmektedir;

Sinıf yönetimi konusunda orta derecedeyim diyebilirim. Her zaman üzerine bir şey eklemeye çalışıyorum, arkadaşlarımı gözlemlemeye çalışıyorum. Doğru bir şey görünce ben de deneyip uygulamak istiyorum. Yumuşak huylu bir insan olduğum için velilerle iletişim konusunda biraz kendimi geliştirmem gerekiyor. Hayır diyemiyorum ve bazen bu konuda kendim zarar görüyorum. Üniversiteyi açık ögretimde okuduğum için bazı konularda eksikliklerim var. Kendim araştırarak okuyarak kendimi geliştirmeye çalışıyorum üniversite eğitimimdeki açı̆̆ı araştırıp okuyarak kapatmaya çalışıyorum.

Sonuç olarak Ö-2'nin sınıfında ki gözlemler, Ö-2 ile yapılan mülakatlar, Ö-2'nin günlük planlarının incelenmesi ve Şekil 3 ile Şekil 4'ün karşılaştırılması sonrasında Ö-2'nin disiplin ve 
sınıf yönetiminde kendine inançları ile sergilediği davranışlar arasında çok büyük olmasa da bazı farklı1ıklar olduğu görülmektedir. Bu farklılıklara ilişsin yorumlar tartışma kısmında verilecektir.

\section{3. Ö-3'ün Disiplin ve Sınıf Yönetimi Profili}

Bu kısımda Ö-3'ün sınıfta sergilediği davranışlar ve sınıf yönetimi ile ilgili inanç ve düşüncelerinin yer aldığı bulgular ele alınacaktır.

\subsection{1. Ö-3'ün Sınıfta Sergilediği Davranışlar}

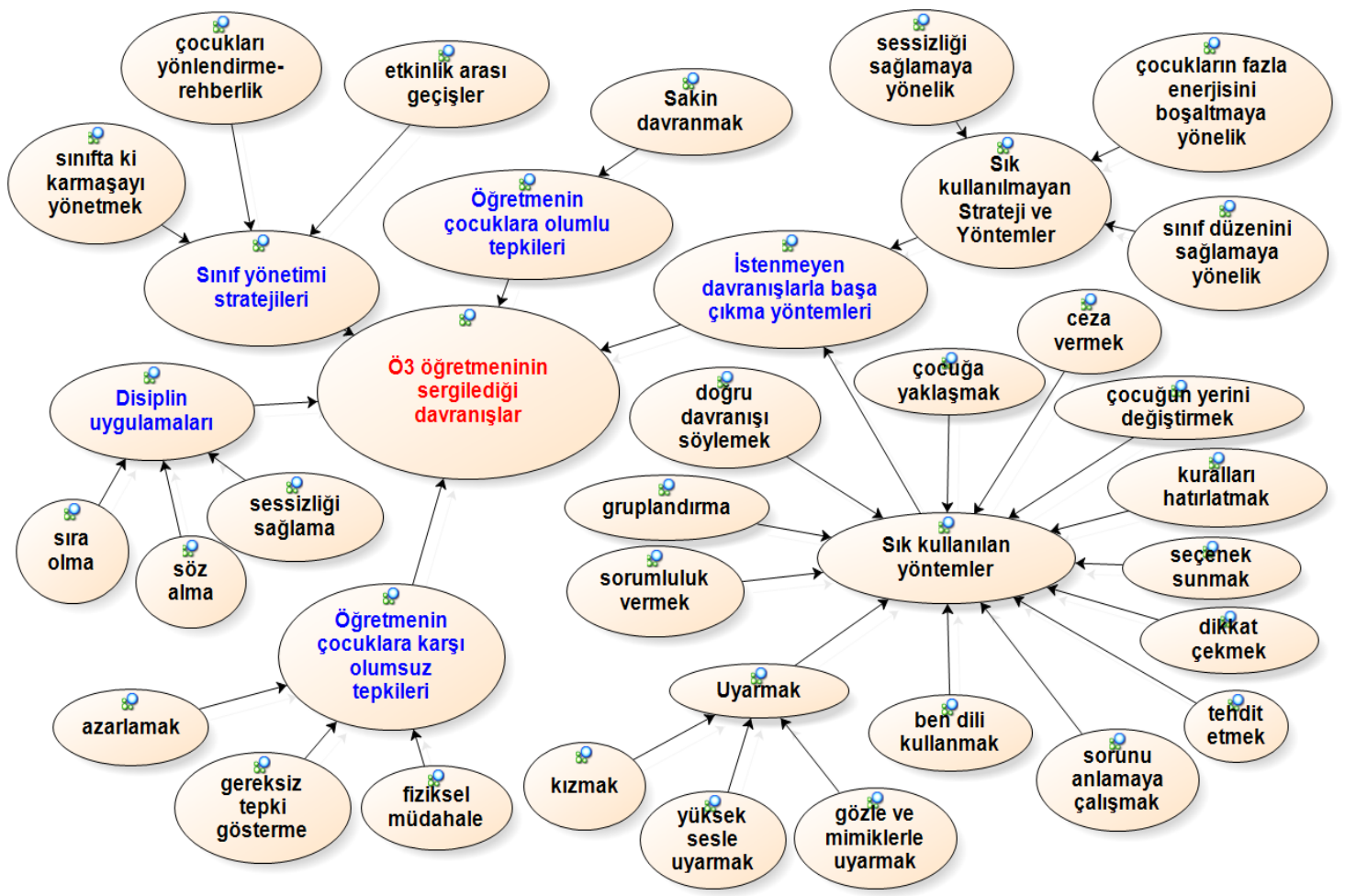

Şekil 5. Ö-3'ün sınıfta sergilediği davranışlara ait kodlamaların gösterildiği model

Ö-3'ün sınıfında yapılan gözlemler ve öğretmenin günlük planlarının incelenmesinden elde edilen bulgulara ilişkin kod ve temalar Şekil 5'te gösterilmiştir. Ö-3'ün sınıfta sergilediği davranışların gösterilmesi amacıyla oluşturulan modelde öğretmenin disiplin uygulamaları, sınıf yönetimi stratejileri, istenmeyen davranışlarla başa çıkma yöntemleri, çocuklara karşı olumlu davranışları ve çocuklara karşı olumsuz davranışları ve alt başlıkları gösterilmiştir. 
Ö-3'ün sınıf içinde genelde sakin ve sabırlı davrandığı ve bu rahat tavrı ile ortaya çıkabilecek birçok olumsuz davranışın önüne geçebildiği görülmüştür. Sınıfta yapılan bir gözlem sırasında ise öğretmenin ve çocukların çok gergin olduğu ve Ö-3'ün sınıfında yapılan diğer 6 gözlemde hiç karşılaşılmayan olumsuz öğretmen davranışlarının sergilendiği görülmüştür. Söz konusu gözlem günü Ö-3 okul bünyesinde yapılacak olan anneler günü etkinliği için kendisine okul yönetimi tarafindan yapılması söylenen müzikli oyunları çalıştırmaktaydı. Oyunlar için iki ayrı grup oluşturulmuştu ve Ö-3'ün komutuyla gruplar ezberledikleri dans hareketlerini yapmaya çalışıyorlardı. Etkinlik planlarını uygularken oldukça sakin olan Ö-3'ün, bu durumda oldukça gergin olduğu fark edilmiştir.

Gözlemlerde Ö-3'ün sınıfın toplanması esnasında sınıf çok küçük olduğu için tüm çocukların toplamada çok zorlandığını ve karışıklık olduğunu fark ederek toplanma işini bir gün kızlar bir gün erkekler yapacak şekilde sıraya koyduğu ve hem sınıfta karmaşa yaşanmadan bu geçişi sağlamayı başardığı hem de çocukların rekabet duygularından faydalanarak işlerini en iyi şekilde yapmalarını sağladığı görülmüştür.

\subsection{2. Ö-3’ün Sınıf Yönetimi ile İlgili İnanç ve Düşünceleri}

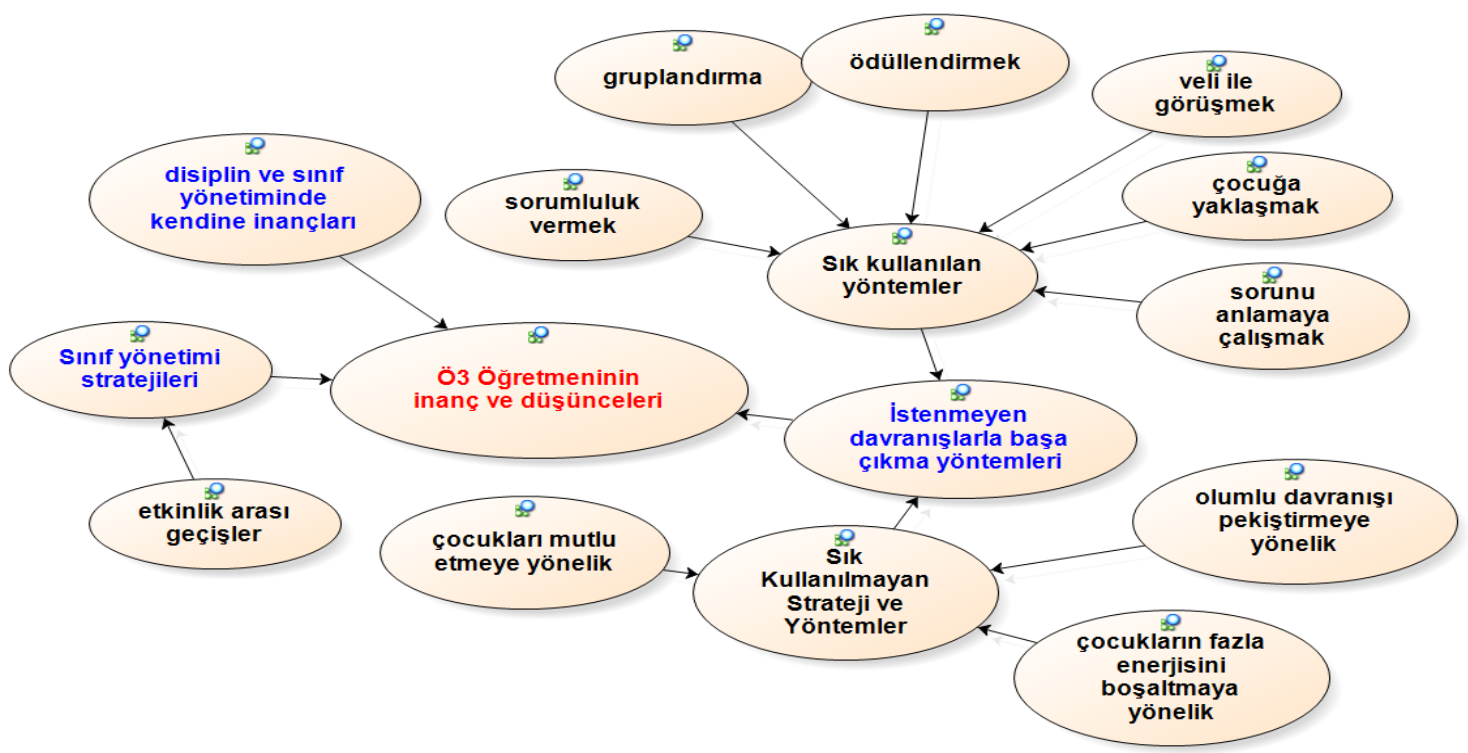

Şekil 6. Ö-3’ün sınıf yönetimine ilişkin inanç ve düşüncelerine ait kodlamaların gösterildiği model

Ö-3 ile yapılan mülakatların incelenmesinden elde edilen bulgulara ilişkin kod ve temalar şekil 6'da gösterilmiştir. Ö-3'ün sınıf yönetimi ile ilgili inanç ve düşüncelerinin gösterilmesi amaciyla oluşturulan modelde öğretmenin sınıf yönetimi stratejileri, disiplin ve sınıf yönetiminde kendine inançları ile istenmeyen davranışlar ile başa çıkma yöntemleri ve alt başlıkları gösterilmiştir.

Ö-3'ün sınıfta istenmeyen davranışlarla başa çıkma yöntemlerinden sık kullanılan yöntemler ile ilgili daha fazla görüş belirttiği ve "ödüllendirmek", "sorumluluk vermek", "gruplandırma", "veli ile görüşmek", "çocuğa yaklaşmak" ve " sorunu anlamaya çalışmak" yöntemlerini kullandığını belirttiği Şekil 6'da görülmektedir.

Ö-3 disiplin ve sınıf yönetimindeki başarısını ve bu konuda kendine olan inancını şu şekilde ifade etmektedir;

Sınıf yönetimi ile ilgili olarak genelde başarılı olduğumu düşünüyorum. Ama bu konuda mükemmelim diyemem. Şu anda daha yeni öğretmenim, ne olduğunu henüz 
keşfedemedim ama şu ana kadar yürüttüğüm sistemin de verimli olduğunu düşünüyorum. Çok iyi değil ama memnunum. Başta anlamadım, çözmekte zorlandım ve çok sıkıntı yaşıyordum ama yavaş yavaş yaşayarak ögrrendim sanırım. Sınıfın düzenini sağlamaya çalışırken ilk olarak "bu çocukları nasıl mutlu edebilirim" diye düşünüyorum. Çünkü çocukların mutlu oldukları bir ortamda olumsuz davranışlara yönelmeyeceğine inanıyorum.

Ö-3'ün sınıfında ki gözlemler, Ö-3 ile yapılan mülakatlar, Ö-3’ün günlük planlarının incelenmesi ve Şekil 5 ile Şekil 6'nın karşılaştırılması sonucunda Ö-3'ün disiplin ve sınıf yönetiminde kendine inançları ile sergilediği davranışlar arasında farklılıklar olduğu görülmektedir. Bu farklılıklara ilişkin yorumlar tartışma kısmında verilecektir.

\section{TARTIŞMA ve SONUÇ}

Öğretmenler ile ilgili bulgulara bakıldığında genel olarak 3 öğretmenin de inançları ile davranışları arasında farklar olduğu ve bu farkların çeşitli nedenlerden kaynaklandığı gözlenmiştir. Üç öğretmenin sınıf yönetimi, disiplin ve istenmeyen davranışlarla başa çıkma konusundaki inanç ve düşünceleri ile sınıf içi sergiledikleri davranışlar göz önünde bulundurulduğunda inançların uygulamaya yansıtılmasında tecrübenin etkili olduğu görülmüştür. Aynı şekilde Demirel (2004) yaptığı çalışmada öğretmenlerin etkili sınıf yönetimi için gerekli bilgi birikimine ve bu bilgileri uygulama becerisine sahip olması gerektiğini savunmaktadır. Aralarında en tecrübeli olan Ö-1'in inançları ile davranışları karşılaştırıldığında daha fazla bir tutarlılık söz konusu olduğu tespit edilmiştir.

Öğretmenlerin inanç ve davranışları ile ilgili bulgular, sınıf yönetimi stratejilerinin daha çok davranış temelli olduğunu göstermiştir (Neisworth ve Buggey, 2009; Özgün, 2008). Öğretmenler geleneksel (sık kullanılan) sınıf yönetimi stratejileri ile çocukların davranışlarına müdahale etme inancını ve eğilimini göstermektedirler. Etkili bir sınıf yönetiminde öğretmen inançlarının yanında sınıf iklimi, etkinlik planlarında sınıf yönetiminin de göz önünde bulundurulması ve ortamın düzeni de önemli bir yere sahiptir. Çalışmada öğretmenlerin sınıf yönetimi hususunda, sınıf atmosferi hakkında inanç ve görüşlerini belirtmemesi ilginçtir. Öğretmenlerin inançları incelendiğinde dikkat çeken bir başka nokta ise çocukların özdenetimi geliştirmeye yönelik herhangi bir stratejinin ön plana çıkmamasıdır. Elde edilen veriler disiplinin otorite figürü ile mümkün olabileceğini göstermiştir. Erol'un (2006) çalışmasında öğretmenlerin liderlik vasfına sahip, bilgi birikimlerini etkili kullanabilen bireyler olması gerektiğini belirten düşüncesi de bu görüşü desteklemektedir.

Bir diğer dikkat çekici sonuç ise, öğretmenlerin sessizliği sağlamaya yönelik çabasıdır. İstenmeyen davranışlarla başa çıkma yöntemlerinden biri olarak, sınıf içerisinde sessiz bir ortamın devamlılığı, öğretmenlerde iyi bir sınıf yönetimi inancını pekiștirmiștir. Diğerlerinden farklı olarak bir öğretmen çocukların fazla enerjisinin açığa çıkarıldığında, sınıf yönetimini sağlayabileceğine inanmaktadır. Doğan Burç'un (2006) çalışmasında da çocuklar fiziksel olarak rahat olmasının tüm dikkatlerini ve enerjilerini uygulanan etkinliğe verebilmesi açısından önemli olduğunu vurguladığı görülmektedir. Fakat bu inancın istenmeyen davranışlarla başa çıkma stratejisi olarak sınıf içinde sergilenmediği de gözlenmiştir.

Araştırma verileri öğretmenlerin sınıf yönetimi inançlarını etkinlik planlarına yansıtamadıklarını göstermiştir. Öğretmen inançlarının planlara yansımaması, sınıf içi sergilenen davranışların anlık, sık kullanılan yönetmeler olmasına neden olmaktadır. Sınıf yönetimi ve disiplin inançlarının planlarda yer almaması, öğretmenlerin sınıf yönetimi konusunda yeterli eğitim almamasından kaynaklanabilir. Oysaki tutarlı ve planlı bir sınıf yönetimi, verilen eğitimin kalitesini doğrudan etkileyecektir. 
Bir öğretmenin yapabileceklerinin ve yetersizliklerinin farkında olabilmesi gereklidir. $\mathrm{Bu}$ farkındalığın öğretmenleri eksiklerini tamamlama ve güçlü yönlerini ön plana çıkarma konusunda olumlu etkileyeceği düşünülebilir. 3 öğretmenin de görüşleri göz önünde bulundurulduğunda aldıkları öğretmen eğitimini yetersiz buldukları görülmüsştür. Sınıf yönetimi ve disiplin yöntemleri gibi bazı durumlar ile ilgili eksik ya da yanlış bilgi sahibi oldukları için öğretmenlerin kendilerini yetersiz hissettikleri veya yetersiz kaldıklarının farkına varamadıkları görülmüştür. Öğretmenlerin söylemlerinden yola çıkarak şekillenen düşünceme göre üniversitelerde verilecek eğitimlerde sınıf içi uygulamaların ve okul deneyimi çalışmalarının daha fazla yapılması ve özellikle sınıf yönetimi ve disiplini ile ilgili etkinliklerin içeriklerinin dikkatle hazırlanması faydalı olacaktır. Öğretmenlerin sık sık geleneksel disiplin yöntemlerini ve sınıf yönetimi stratejilerini kullandığı fark edilmiş̧tir ve bunun sebebinin de öğretmenlerin yeniliğe açık bir anlayışla eğitilmemiş olmalarından kaynaklanabileceği düşünülmektedir (Hiralall ve Martens, 1998). Ocak ve Arda'nın da (2014) belirttiği üzere, istenmeyen davranışlara yönelik uygulanmakta olan çağdaş ve farklı yaklaşımları ülkemizde derinlemesine tartışılmasına ihtiyaç duyulmaktadır.

Bulgulardan elde edilebilecek genel sonuç öğretmenlerin somut sınıf yönetimi stratejileri oluşturmaktan uzak oldukları ve daha çok anlık çözümler sunan, krizi atlatmaya yönelik uygulamalar yaptıkları yönündedir. Ayrıca öğretmenlerin etkili zaman yönetimi konusunda farkındalıklarının az olduğu gerek planlamaları gerekse sınıf içi uygulamalarında zaman yönetimi konusuna çok önem vermedikleri söylenebilir. Çalışmada öğretmenlerin daha çok doğal yollar ile elde ettikleri tecrübelere ve herkes tarafindan bilinen geleneksel yöntemlere dayanarak kendi stratejilerini oluşturdukları gözlenmiştir. Öğretmenlerin sınıflarındaki çocuk profilini veya sorun davranışları ele alarak sınıf yönetimi stratejilerini belirlemek yerine geleneksel yöntemleri kullanmayı daha çok tercih ettikleri fark edilmiştir. Oysaki öğretmenin, istenmeyen davranışın farkında olması problemin giderilmesini kolaylaştıracaktır (Kapucuoğlu Tolunay, 2008). Çalışmadan elde edilen sonuçlar şu şekilde sıralanabilir;

- Öğretmenlerin profesyonel tutumdan uzak davrandıkları ve tutarsız davranışlar sergiledikleri gözlenmiştir. Uygulamalarının çocuk üzerindeki etkisinin ve sonuçlarının farkında olmadan bilinçsizce bir sınıf yönetimi yürütmeye çalıştıkları fark edilmiştir.

- Öğretmenlerin planları, uygulamaları ve düşünceleri arasında uyum olmadığı söylenebilir.

- Öğretmenlerin daha çok ürün odaklı çalışmalar üzerinde durduğu ve süreçten çok sonuçlara önem verdiği gözlenmiştir. Öğretmenlerin planlamalarını çocuk merkezli değil de etkinlik merkezli yaptıkları fark edilmiştir. Bu durumun öğretmenlerin geleneksel yöntem ve stratejilere daha yakın olmalarından kaynaklandığı düşünülebilir.

- Öğretmenler belirli gün ve hafta kutlamaları ile okul gösterileri gibi kendi iradeleri dışında planladıkları, inanmadıkları ve istemedikleri etkinlikleri gerçekleştirirken sınıf yönetimi ve disiplini konusunda daha sert ve plansız olabilmektedirler. Planlaması yapılmayan etkinlik süreci gerçekleştirilirken sorunlar yaşanmaktadır.

\section{KAYNAKLAR}

Akar, İ. (2006). Öğrenci davranışlarını etkileyen etmenler. (Ed. Z. Kaya), Sınıf Yönetimi içinde, Ankara: Pegem Akademi Yayınc1lık.

Akar, H., Tor, D., Tantekin-Erden, F., ve Şahin, İ.T. (2010) . Öğretmenlerin sınıf yönetimi yaklaşımları ve deneyimlerinin incelenmesi. İlkögretim Online, 9(2), 792-806. Http://İlkogretim-Online.Org.Tr Adresinden 10 Mart 2011 Tarihinde Edinildi. 
Akçadağ, T. (2005). Sorun davranışların yönetimi. (Ed: H. Kıran), Etkili Sınıf Yönetimi içinde, Ankara: Anı Yayıncilik.

Akgün, E., Yarar, M. ve Dinçer, Ç. (2011). Okul öncesi öğretmenlerin sınıf içi etkinliklerde kullandıkları sınıf yönetimi stratejilerinin incelenmesi. Pegem Eğitim ve Öğretim Dergisi / 2011 Cilt: 1, Sayı: 3

Aktaş Arnas, Y. ve Sadık, F. (2008). Okul öncesi eğitimde sınıf yönetimi (1. Baskı). Ankara: Kök Yayıncılık.

Balay, R., ve Sağlam, M. ( 2008). Sınıf içi olumsuz davranışlara ilişkin öğretmen görüşleri. Yüzüncü Yıl Üniversitesi Eğitim Fakültesi Dergisi, 5, 1-24.

Başal, H. A. (2005). Okul Öncesi Eğitiminin İlke ve Yöntemleri (Genişletilmiş 2. Baskı). İstanbul: Morpa Kültür Yayınları.

Başar, H. (2000). Sinıf Yönetimi. Ankara: Şafak Matbaacılık.

Bear, G. G. (1998). School discipline in the United States: Prevention, correction, and long-term social development. School Psychology Review, 27, 14-32.

Berg, B. L. (2001). Qualitative Research Methods for the Social Sciences (4th Ed.). MA, ABD: Allyn and Bacon.

Büyüköztürk, Ş., Çakmak, E.K., Akgün, Ö.E., Karadeniz, Ş., \& Demirel, F. (2014).Bilimsel Araştırma Yöntemleri (18. Bask1).Ankara: Pegem Akademi.

Bredekamp, S. (2015) Erken Çocukluk Eğitiminde Etkili Uygulamalar (H.Z. İnan ve T. İnan, Çeviri Ed.). Ankara: Nobel Yayıncilik. (2013).

Carter, K. ve Doyle, W. (2011). Classroom Management in Early Childhood and Elementary Classrooms. In Handbook of Classroom Management: Research, Practice, and Contemporary Issues,(pp373-404). Edited by Edmund Emmer, Edward Sabornie, Carolyn M. Evertson, Carol S. Weinstein, Routledge, Taylor \& Francis Group: New York

Celep, C. (2004). Sinıf Yönetimi ve Disiplini (3. Bask1). Ankara: Anı Yayınc1lık.

Creswell, J. W. (2009). Research Design. California, ABD: Sage Publications.

Cüceloglu, D. (2001). Savaşçı (15. Baskı). İstanbul: Sistem Yayıncılık.

Çakır, N. (2010). Okul öncesi öğretmenlerinin disiplin anlayışları ile iç-dış denetim odakları arasındaki ilişki (Çanakkale İli Örneği).Yayımlanmamış Yüksek Lisans Tezi. Çanakkale On sekiz Mart Üniversitesi Sosyal Bilimler Enstitüsü, Çanakkale.

Dauncey, L. And Vokes, D. (2012). Case studies into classroom management: Teacher behavior, the use of practicalstrategies, and the use of rules. The Pennsylvania State University The College of Education Spring 2012.

Demirel, Ö. (2004). Kuramdan Uygulamaya Eğitimde Program Geliştirme (4.Baskı). Ankara: Pegem A Yayıncılık.

Denizel-Güven, E. ve Cevher, F. N. (2005). Okul öncesi öğretmenlerinin sinıf yönetimi becerilerinin çeşitli değişkenler açısından incelenmesi. Pamukkale Üniversitesi Ĕgitim Fakültesi Dergisi, 2(18), 1-22.

Doğan Burç, E. (2006). İlköğretim okulu öğretmenlerinin sınıf yönetimi yeterlilikleri (Hatay İli Örneği) Yayımlanmamış Yüksek Lisans Tezi, Abant İzzet Baysal Üniversitesi Sosyal Bilimler Enstitüsü, Bolu.

Dönmez, B. ve Cömert, M.(2009) Öğretmen adaylarının, kendilerinin ve uygulama öğretmenlerinin sınıf içi istenmeyen öğrenci davranışları ile baş etme konusundaki yeterliklerine ilişkin algıları. Ahi Evran Üniversitesi Eğitim Fakültesi Dergisi,10(2), 47-55.

Erdem, E. \& Demirel, Ö. (2002). Program Geliştirmede Yapılandırmacılık Yaklaşımı. Hacettepe Üniversitesi Eğitim Fakültesi Dergisi 23: 81-87.

Ergün, M. ve Duman, T. (2007). Kritik durumlarda öğretmen davranışları II. Http://Yayim.Meb.Gov.Tr/Dergiler/145/Ergun.Htm.

Erol, Z. (2006) Sınıf öğretmenlerinin sınıf yönetimi uygulamalarına ilişkin görüşleri. Yayımlanmamış Yüksek Lisans Tezi, Afyon Kocatepe Üniversitesi Sosyal Bilimler Enstitüsü, Afyonkarahisar.

Esen, H. (2006). İlk ve ortaöğretim okullarında görev yapan öğretmenlerin kullandıkları disiplin türleri ( Edirne İli Örnefği). Yayımlanmamış Yüksek Lisans Tezi. Trakya Üniversitesi. Edirne.

Ferk, M. K. (2009). Avoiding Chaos in the Preschool Classroom: Management Methods and Techniques.. [Available online at:http://mkferk5235.files.wordpress.com/2009/11/professionalism-paper.pdf.], Retrieved on February13, 2014. 
Fraenkel, J. ve Wallen, N. (2008). How To Design and Evaluate Research in Education. (7th Ed.). USA: McGrawHill Companies, Inc.

Gall, J. P., Gall, M. D. and Borg, W. R. (1999).Applyingeducationalresearch: A practicalguide. New York: Longman.

Gettinger, M., \& Fischer, C. (2015). Early childhood education classroom management. In E.T. Emmer \& E. J. Sabornie (Eds.). Handbook of classroom management: Research, practice, and contemporary issues $\left(2^{\text {nd }}\right.$ ed.). New York, NY: Routledge, Taylor and Francis.

Gezgin, N. (2009). Okul öncesi eğitimi öğretmenlerinin kullandıkları sınıf yönetimi stratejileri. Yayımlanmamış Yüksek Lisans Tezi, Uludağ Üniversitesi Sosyal Bilimler Enstitüsü, Bursa.

Hiralall, A. S., ve Martens, B. K., (1998). Teaching classroom management skills to preschool staff: The effects of scripted instructional sequences on teacher and student behavior. School Psychology Quarterly, Vol 13(2), 1998, 94-115.

Hoy, A. W., \& Weinstein, C. S. (2006). Student and teacher perspectives on classroom management. In C. M. Evertson \& C. S. Weinstein (Eds.), Handbook of classroom management: Research, practice and contemporary issues (pp. 181-222). Mahwah, NJ: Lawrence Erlbaum Associates Publishers.

İlgar, L. (2007). İlköğretim öğretmenlerinin sınıf yönetimi becerileri üzerine bir araştırma. Yayımlanmamış doktora tezi, İstanbul Üniversitesi, İstanbul.

Kafle, N. P. (2013) Classroom management: a concern for educational leaders. Wudpecker Journal of Educational Research,Vol. 2(4), pp. 057 - 061, April 2013

Kapucuoğlu Tolunay, A. (2008). Sınıf öğretmenlerinin sınıfta karşılaştıkları istenmeyen öğrenci davranışları ve bu davranışlara karsı kullandıkları baş etme yöntemleri. Yayımlanmamış Yüksek Lisans Tezi, Uludağ Üniversitesi Sosyal Bilimler Enstitüsü, Bursa.

Kazu, H. (2007).Öğretmenlerin sınıfta istenmeyen davranışların önlenmesi ve değiştirilmesine yönelik stratejileri uygulama durumları. Milli Eğitim Dergisi, 175,5 7-66.

Katz, L.G. \& Chard, S.C. (2000). The project approach (2nd ed.). Stamford, CT: Ablex Publishing Company.

Kent Kükürtçü, S. (2011). 5-6 yas çocuklarının ailelerinin ve öğretmenlerinin kullandıkları disiplin yöntemlerinin çocuk hakları ile ilişkisinin incelenmesi. Hacettepe Üniversitesi Sosyal Bilimler Enstitüsü, Ankara.

Kısa, D. (2009). Okulöncesi öğretmenlerinin altı yaş çocuklarının sorumluluk eğitiminde başvurdukları disiplin yöntemlerine ilişkin görüşleri. Yayımlanmamış Yüksek Lisans tezi, Adnan Menderes Üniversitesi Sosyal Bilimler Enstitüsü, Aydın.

McMillan, J. H. (2004). Educationalresearch: Fundamentals for the Consumer (4th Edition). Boston: Person.

Morris, P.,Raver, C., Lloyd, C. M. and Millenky, M. (2009). Can Teacher Training in Classroom Management Make a Difference for Children'sExperiences in Preschool? A Preview of Findingsfrom the Foundations of Learning Demonstration. [Availableonline at: http://www.mdrc.org/sites/default/files/full_44.pdf.], Retrieved on February $15,2014$.

Neisworth, J. and Buggey, T. (2009) Behavior Analysis and Principles in Early Childhood Education. In J Roopnarine and J. Johnson, (Eds) (2009) Approaches to Early Childhood Education (5 ed. Pp.186-210). Upper Saddle River, NJ: Merrill/Prentice Hall.

Nourt, P. M. (2009). Historical Perspectives on Early Childhood Education. In J Roopnarine and J. Johnson, (Eds) (2009) Approaches to Early Childhood Education (5 ed. Pp.3-48). Upper Saddle River, NJ: Merrill/Prentice Hall.

Ocak, Ş. ve Arda, T. B., (2014). Okul öncesi dönemde önleyici müdahale edici programların karşılaştırılması. Hacettepe Üniversitesi Eğitim Fakültesi Dergisi [Hacettepe University Journal of Education], 29(4), 171-188.

Özer, G. (2009). Öğretmen adaylarının sınıf içinde gözlemledikleri istenmeyen öğrenci davranıșları ve bu davranışlarla bas etmede kullanılabilecek stratejilere ilişkin görüşleri. Yayımlanmamış Yüksek Lisans Tezi, Zonguldak Karaelmas Üniversitesi Sosyal Bilimler Enstitüsü, Zonguldak.

Özgün, Ö.(2008). Sınıfta İstenmeyen Davranışlar, Nedenleri, Yönetimi. Yaşare Aktaş Arnas\& Fatma Sadık(Ed.), Okul Öncesi Eğitimde Sınıf Yönetimi içinde (s.243-276). Ankara: Kök Yayıncılık.

Öztürk, B. (2002). Sınıfta İstenmeyen Davranışların Önlenmesi ve Giderilmesi. E. Karip(Ed.), Sınıf Yönetimi içinde. Ankara: PEGEM Yayınları. 
Raver, C. C., Jones, S. M., Li-Grining, C. P., Metzger, M., Champione, K. M., \& Sardin, L. (2008). Improving preschool classroom processes: Preliminary findings from a randomized trial implemented in Head Start settings. Early Childhood Research Quarterly, 23, 10-26.

Sadık, F. (2004). Okul öncesi sınıflarda gözlenen problem davranışlar ve bu davranışlarla baş etmede öğretmenlerin kullandıkları yöntemler. Eğitim Araştırmaları Dergisi, sy. 13, ss. 89-97.

Sipahioğlu, E. (2008). İlköğretim I. kademede sınıf içi istenmeyen öğrenci davranışları ve çözüm önerileri (Narlıdere İlçesi Örneği). Yayımlanmamış Yüksek Lisans Tezi, Beykent Üniversitesi Sosyal Bilimler Enstitüsü, İstanbul.

Slider, N.J.,Noell, G. H. and Williams, K. L. (2006).ProvidingpracticingteachersClassroom management professionaldevelopment in abrief self-study format. JBehavEduc. 15, 215-228.

Stake, R. (1995). The art of case study research. Newbury Park, CA: Sage Publications.

Tertemiz, N. (2005). Sınıf Yönetimi ve Disiplini. L. Küçükahmet (Ed.), Sinıf Yönetimi içinde. Ankara: Nobel Yayın Dağıtım

Webster-Stratton, C. (1999). How to promote children's social and emotional competence. Thousand Oaks, CA: Paul Chapman Publishing Ltd.

Webster-Stratton, C. \& Reid, M. J. (2010). The Incredible Years Parents, Teachers, and Children Training Series: A Multifaceted Treatment Approach for Young Children with Conduct Disorders. In J. R. Weisz \& A. E. Kazdin (Eds.) Evidence-Based Psychotherapies for Children and Adolescents (pp. 194-210). New York and London: The Guilford Press.

Yaman, B. (2010). Pedagojik formasyon eğitimi almamış öğretmenlerin sınıf yönetimi algıları/Aksaray ili örneği. Elektronik Sosyal Bilimler Dergisi, C 9, Sayı 31, s. 53-72.

Yavuzer, H.(2006). Çocuk Eğitimi El Kitabı. İstanbul: Remzi Kitabevi.

Yıldırım, A. ve Şimşek, H. (2006). Sosyal Bilimlerde Nitel Araştırma Yöntemleri. Ankara: Seçkin Yayıncılık.

Yılmaz, N. (2007). Sınıf Öğretmenlerinin Sınıf İçi Disiplin Sağlamada Kullandıkları Ödül ve Ceza Yöntemlerinin Değerlendirilmesi. Yayımlanmamış Yüksek Lisans Tezi. İstanbul, Yeditepe Üniversitesi.

\section{Extended Abstract}

It is one of the hardest issues for teachers to create an effective learning environment in their classroom while struggling with children's inappropriate or disturbing behaviors. The first step to handle with these undesirable or bad behaviors in the classroom is to identify the behaviors and to find the cause or the source of the problems. If the teacher knows what causes the behavioral problems, she or he can easily eliminate them (Kapucuoğlu Tolunay, 2008). Children behaviors are conceptualized in different ways. On the one hand, behaviorist theorists see children's behaviors as consequences of stimulus. They analyzed children's action in a deterministic perspective that if there is an appropriate reinforcement or motivation exist, the targeted action comes after (Neisworth ve Buggey, 2009; Özgün, 2008). On the other hand, constructivist theorists such as Piaget and Vygotsky, draw attention on children's cognitive understanding of their own actions. If children realized or conceptualized the the process of their own behaviors, they will construct new ones (Erdem ve Demirel, 2002; Özgün, 2008). Every teacher has her own methods and strategies to manage disruptive behaviors in her classroom. However, each of them also needs to adapt their management styles according to structure of the classroom and attributes of the children (Tertemiz, 2005). Discipline process in education could be described as keeping classroom order in a best way and ensuring this order until fulfilling the targeted educational goals (Esen, 2006). The classroom environments which teachers organize could be common in somehow, but teachers' implementations will differ from each others. Thus, the variety of teachers' knowledge and competences related to classroom management and discipline strategies will affect the quality of the implementation.

Analyzing research done in this field, it could be seen that there are plenty of works has been done about determining and reasoning disruptive behaviors in classroom (Kapucuoğlu Tolunay, 2008; Özer, 2009; Sadık, 2004). There are also studies about strategies on building up classroom discipline and eliminating unwanted behaviors (Sipahioğlu, 2008; Yılmaz, 2007). However, there is very little research 
on teachers' beliefs and views about coping with children's disruptive behaviors, managing classrooms, and implementing disciplines. This study aims to fill this gap in the literature. For a research methodology, case study was selected for this work. The data was collected through document analysis including analyzing teachers' instructional plans, interviews with the participated teachers, and observation of these teachers in their classrooms. There are three participants of this study, who were selected from the teachers who worked in a public school in Trabzon. The participants were coded as $\ddot{O}-1$, Ö-2, Ö-3. Each code was used to interpret and analyze the data gathered from semi structured in class observations and interviews, and the teachers' documents. In the first stage, the researcher visited to each teacher's classroom once in a week and she made seven observations of each. The observation period was a maximum of two hours. In the second, the research interviewed each participant twice. Each interview was recorded and transcribed. Every interview took half an hour long. In the third stage, the participants' instructional plan and materials belong to the day of observation was reviewed and analyzed after careful transcription. The whole data was analyzed altogether by using Nvivo 8 , which is a qualitative data analyzing program.

Findings of the study have showed that the beliefs of three teachers about classroom management and discipline are different from their practices in the classrooms. While some teachers have straight and clear beliefs about classroom management and they could not practice what they believe in their classroom; some do not have straightforward beliefs, however they could reflect clearly their belief on their practices. There are different reasons for why the teachers act different from their beliefs. One teacher claimed that the more you have teaching experience the stronger belief you have. Another teacher asserted that if a teacher knows her capabilities and has strong self confidence, she can have strong belief about discipline. All of them indicated in the interviews that they had limited courses about classroom management during their teacher training program. It was also observed that the teachers sometimes felt inadequate to intervene some specific disruptive behaviors during activity time. They had also problem with identifying disruptive behaviors and eliminating them (Kapucuoğlu Tolunay, 2008).

According to the results, the Ö-1, had strong self confidence about classroom management and she indicated that she had gained this confidence over the years. The Ö-2 did not show strong self confidence and beliefs about classroom management and she cleared out that she has been attending in-service training to fill up the gap from her teacher education. The Ö-3 was not confident in classroom management and discipline, but she could manage to keep activities in order in her classroom.

In conclusion, the study showed that the teachers were not consistent what they believed and what they did about managing the classrooms and disciplining children's unwanted behaviors. Considering the data holistically, it could be concluded that the teachers had pursued inconsistent classroom management strategies regardless of their effects on the children's behaviors. Previous studies have shown that teachers should set clear and precise rules for the children in the classroom in order to manage the group and reach the goals (Carter \&Doyle, 2011; Bear, 1998; Webster-Stratton, 1999). In our study, the teachers were seen to fail to set the consistent rules and accomplish the goals. 